\title{
Lactomycins A-C, Dephosphorylated Phoslactomycin Derivatives That Inhibit Cathepsin B, from the Marine-Derived Streptomyces sp. ACT232
}

\author{
Yi Sun ${ }^{1, \dagger}$, Rogie Royce Carandang ${ }^{1}$, Yuta Harada ${ }^{1}$, Shigeru Okada ${ }^{1}$, Kazutoshi Yoshitake ${ }^{2}$, \\ Shuichi Asakawa ${ }^{2}$, Yuichi Nogi ${ }^{3}$, Shigeki Matsunaga ${ }^{1, *}$ and Kentaro Takada ${ }^{1, *}$ \\ 1 Laboratory of Aquatic Natural Products Chemistry, Graduate School of Agricultural and Life Sciences, \\ The University of Tokyo, Tokyo 113-8657, Japan; sylotus@hotmail.com (Y.S.); rrzc_8@yahoo.com (R.R.C.); \\ y_harada0609@yahoo.co.jp (Y.H.); aokada@mail.ecc.u-tokyo.ac.jp (S.O.) \\ 2 Laboratory of Aquatic Molecular Biology and Biotechnology, Graduate School of Agricultural and Life \\ Sciences, The University of Tokyo, Tokyo 113-8657; akyoshita@g.ecc.u-tokyo.ac.jp (K.Y.); \\ asakawa@mail.ecc.u-tokyo.ac.jp (S.A.) \\ 3 Japan Agency for Marine-Earth Science and Technology (JAMSTEC), Natsushima, Yokosuka, \\ Kanagawa 237-0061, Japan; nogiy@jamstec.go.jp \\ * Correspondence: assmats@mail.ecc.u-tokyo.ac.jp (S.M.); atakada@mail.ecc.u-tokyo.ac.jp (K.T.); \\ Tel.: +81-3-5841-5297 (S.M.); +81-3-5841-5301 (K.T.) \\ + Present address: Institute of Chinese Materia Medica, China Academy of Chinese Medical Sciences, \\ Beijing 100700, China
}

Received: 12 December 2017; Accepted: 12 February 2018; Published: 21 February 2018

\begin{abstract}
Three new polyketides, lactomycins A (1)-C (3), were isolated from the culture broth of a marine-derived Streptomyces sp. ACT232 as cathepsin B inhibitors. Their structures were determined by a combination of NMR and MS data analyses to be the dephosphorylated derivatives of a phoslactomycin class of metabolites. Lactomycins exhibited cathepsin B inhibitory activity $\left(\mathrm{IC}_{50}\right.$ 0.8 to $4.5 \mu \mathrm{g} / \mathrm{mL}$ ). Even though the biosynthetic gene clusters found in the genome of the current strain have high similarity to those of phoslactomycin, neither phoslactomycins nor leustroducsins were detected by LC-MS analyses of the crude extract.
\end{abstract}

Keywords: Streptomyces; cathepsin B; enzyme inhibitory; phoslactomycin

\section{Introduction}

The majority of the structurally and functionally diverse anticancer agents have been derived from terrestrial naturel products [1]. Although marine organisms were reported to exhibit a high incidence of cytotoxic activity [2], it is only recently that a few anticancer agents derived from marine organisms have been approved [3]. We have been searching for anticancer compounds from marine organisms [4], and payed attention to cathepsin B as a target to discover anticancer agents with a mode of action distinct from cell cycle arrest. Cathepsin B is a lysosomal protease of the papain family, which has been considered as a superb target for cancer chemotherapy [5]. It is activated and secreted in the tumor microenvironment and enhances tumor metastasis and infiltration by cleaving extracellular matrix proteins and activating several prominent proteases. It is overexpressed in various cancers and its knockout retards cell proliferation and tumor growth. During our screening program it was found that the crude extract of the Streptomyces sp. ACT232, a marine-derived actinomycete, showed cathepsin B inhibitory activity [6]. We isolated and studied the structures and biosynthesis of the active constituents. 


\section{Results}

\subsection{Isolation}

The mycelia from the culture of Streptomyces sp. ACT232 were collected by vacuum filtration. Resins (Amberlite XAD 16N) were added to the filtrate to allow adsorption of the metabolites. The acetone extracts of the mycelia and resins were combined and partitioned between $n$ - $\mathrm{BuOH}$ and $\mathrm{H}_{2} \mathrm{O}$. The $n$ - $\mathrm{BuOH}$ fraction was separated by ODS flash chromatography to give five fractions. The active fraction was separated by reversed-phase HPLC to afford three metabolites termed lactomycins A-C (Figure 1, 1-3).<smiles>CC[C@H]1C=CC(=O)O[C@H]1/C=C/[C@@](O)(CCO)[C@H](O)C[C@H](O)/C=C\C=C/[C@H]1CCC[C@@H](O)[In]1</smiles>

lactomycin A (1)<smiles>CC[C@H]1C=CC(=O)O[C@H]1/C=C/[C@@](C)(O)[C@@H](O)C[C@H](O)/C=C\C=C/[C@H]1CCC[C@@H](O)C1</smiles>

lactomycin C (3)<smiles>CC[C@H]1C=CC(=O)O[C@H]1/C=C/[C@@](O)(CCN)[C@H](O)C[C@H](O)/C=C\C=C/[C@H]1CCC[C@@H](O)C1</smiles>

lactomycin B (2)<smiles>CC[C@H]1C=CC(=O)O[C@H]1/C=C/[C@@](O)(CCN)[C@H](C[C@H](O)/C=C\C=C/[C@H]1CCC[C@@H](O)C1)OP(=O)(O)O</smiles>

leustroducsin $\mathrm{H}(4)$ (phoslactomycin G)

Figure 1. Structures of lactomycins A (1)-C (3) and phoslactomycin G (4).

\subsection{Structure Elucidation}

The molecular formula of lactomycin $\mathrm{A}(\mathbf{1}), \mathrm{C}_{25} \mathrm{H}_{38} \mathrm{O}_{7}$, was established by HRESIMS. The analyses of ${ }^{1} \mathrm{H}$ NMR and HSQC spectra of 1 indicated the presence of eight protonated $\mathrm{sp}^{2}$ carbons $\left(\delta_{\mathrm{H}} / \delta_{\mathrm{C}} 7.03 / 151.5,6.10 / 122.5,6.09 / 121.8,5.96 / 120.5,5.84 / 137.4,5.69 / 123.7,5.40 / 137.6,5.25 / 137.8\right)$, four oxymethines $\left(\delta_{\mathrm{H}} / \delta_{\mathrm{C}} 5.02 / 80.7,4.58 / 63.5,3.53 / 72.6,3.37 / 68.5\right)$, one oxygenated methylene $\left(\delta_{\mathrm{H}} / \delta_{\mathrm{C}}\right.$ $3.53,3.46 / 57.9)$, six methylenes, and one terminal methyl (Table 1). The ${ }^{13} \mathrm{C}$ NMR spectrum revealed the presence of two additional non-protonated carbons at $\delta_{C} 164.0$ and 76.6 (Table 1). Three partial structures of C2-C7 plus C22-C23, C9-C21, and C24-C25 were established by interpretation of the ${ }^{1} \mathrm{H}-{ }^{1} \mathrm{H}$ COSY spectrum. HMBC correlations from $\mathrm{H} 2, \mathrm{H} 3$, and $\mathrm{H} 5$ to the carbon at $\delta_{\mathrm{C}} 164.0(\mathrm{C} 1)$ indicated that $\mathrm{C} 2$ to $\mathrm{C} 5$ comprised an $\alpha, \beta$-unsaturated $\delta$-lactone moiety. There was a 1,3-disubstituted cyclohexane moiety (C16 to $\mathrm{C} 21)$ in the second partial structure, in which $\mathrm{C} 18$ was substituted by an oxygen atom judging from the ${ }^{1} \mathrm{H}$ and ${ }^{13} \mathrm{C}$ NMR chemical shifts $\left(\delta_{\mathrm{H}} / \delta_{\mathrm{C}} 3.37 / 68.5\right)$. The planar structure of the C9 to C15 portion was elucidated by analysis of the COSY spectrum. The third partial structure was composed of disubstituted ethane in which a substituent at $\mathrm{C} 25$ was assigned as an oxygen atom on the basis of the ${ }^{1} \mathrm{H}$ and ${ }^{13} \mathrm{C}$ NMR data $\left(\delta_{\mathrm{H}} / \delta_{\mathrm{C}} 3.46,3.53 / 57.9\right)$. The three partial structures were all attached to the tetrasubstituted carbon bearing an oxygen atom (C8), as demonstrated by HMBC correlations from $\mathrm{H} 7, \mathrm{H} 9$, and $\mathrm{H}_{2}-24$ to $\mathrm{C} 8$. Considering the molecular formula, the oxygen atoms at $\mathrm{C} 8, \mathrm{C} 9, \mathrm{C} 11, \mathrm{C} 18$, and C25 were all assigned as free hydroxyl groups. 
Table 1. ${ }^{1} \mathrm{H}$ NMR (600 MHz) and ${ }^{13} \mathrm{C}$ NMR (150 MHz) Data for $\mathbf{1}$ in DMSO- $d_{6}$ and 2 and 3 in $\mathrm{CD}_{3} \mathrm{OD}$.

\begin{tabular}{|c|c|c|c|c|c|c|c|c|}
\hline \multirow{2}{*}{ Position } & \multicolumn{3}{|c|}{$1\left(\mathrm{DMSO}-d_{6}\right)$} & \multicolumn{3}{|c|}{$2\left(\mathrm{CD}_{3} \mathrm{OD}\right)$} & \multicolumn{2}{|c|}{$3\left(\mathrm{CD}_{3} \mathrm{OD}\right)$} \\
\hline & $\delta_{C}$, Type & $\delta_{H}(J$ in $\mathrm{Hz})$ & HMBC & $\delta_{C}$, Type & $\delta_{\mathrm{H}}(J$ in $\mathrm{Hz})$ & HMBC & $\delta_{C}$, Type & $\delta_{H}(J$ in $\mathrm{Hz})$ \\
\hline 1 & $164.0, \mathrm{C}$ & & & $166.4, \mathrm{C}$ & & & $166.4, \mathrm{C}$ & \\
\hline 2 & $120.5, \mathrm{CH}$ & $5.96, \mathrm{~d}(9.7)$ & 1,4 & $121.1, \mathrm{CH}$ & 6.03, d (9.8) & 1,4 & $120.8, \mathrm{CH}$ & $6.02, \mathrm{~d}(9.8)$ \\
\hline 3 & $151.5, \mathrm{CH}$ & $7.03, \mathrm{dd}(4.7,9.7)$ & $1,4,5$ & $152.8, \mathrm{CH}$ & 7.10, dd $(5.0,9.8)$ & 1,5 & 152.6, $\mathrm{CH}$ & 7.10, dd $(4.7,9.8)$ \\
\hline 4 & $39.1, \mathrm{CH}$ & $2.48, \mathrm{~m}$ & & $40.6, \mathrm{CH}$ & $2.56, \mathrm{~m}$ & & $40.5, \mathrm{CH}$ & $2.53, \mathrm{~m}$ \\
\hline 5 & $80.7, \mathrm{CH}$ & $5.02, \mathrm{dd}(6.5,4.2)$ & $1,3,6,7,22$ & $82.4, \mathrm{CH}$ & $5.10, \mathrm{t}(4.7)$ & & $82.2, \mathrm{CH}$ & $5.06 \mathrm{dd}(4.3,6.7)$ \\
\hline 6 & 123.7, $\mathrm{CH}$ & 5.69, dd $(6.5,15.6)$ & 5,8 & $127.4, \mathrm{CH}$ & $5.97, \mathrm{~m}^{\mathrm{a}}$ & $5,7,8$ & $124.5, \mathrm{CH}$ & $5.87, \mathrm{dd}(6.7,15.7)$ \\
\hline 7 & $137.4, \mathrm{CH}$ & $5.84, \mathrm{~d}(15.6)$ & $5,6,8$ & $136.9, \mathrm{CH}$ & $5.97, \mathrm{~m}^{\mathrm{a}}$ & $5,6,8$ & 139.4, $\mathrm{CH}$ & $6.00, \mathrm{~d}(15.7)$ \\
\hline 8 & 76.6, C & & & $77.9, \mathrm{C}$ & & & $75.6, \mathrm{C}$ & \\
\hline 9 & $72.6, \mathrm{CH}$ & $3.53, \mathrm{~d}(10.0)$ & $7,8,10,11,24$ & $74.7, \mathrm{CH}$ & 3.72, brd $(9.6)$ & 8 & $74.9, \mathrm{CH}$ & 3.68, d (9.7) \\
\hline $10 \mathrm{a}$ & $39.6, \mathrm{CH}_{2}$ & $0.98, \mathrm{~m}$ & 9 & $40.5, \mathrm{CH}_{2}$ & $1.34, \mathrm{~m}$ & 11 & $40.1, \mathrm{CH}_{2}$ & $1.31, \mathrm{~m}$ \\
\hline $10 \mathrm{~b}$ & & $1.58, \operatorname{ddd}(1.4,10.0,12.8)$ & 11 & & $1.75, \mathrm{~m}$ & 9 & & $1.73, \mathrm{~m}$ \\
\hline 11 & $63.5, \mathrm{CH}$ & 4.58, ddd $(1.8,8.4,10.0)$ & $9,10,13$ & $65.5, \mathrm{CH}$ & $4.80^{\mathrm{b}}$ & & $65.0, \mathrm{CH}$ & 4.80, brt $(10)$ \\
\hline 12 & $137.6, \mathrm{CH}$ & 5.40, brt (9) & 10,14 & $135.8, \mathrm{CH}$ & 5.45, brt (9) & 14 & $135.7, \mathrm{CH}$ & 5.46, brt (9) \\
\hline 13 & $121.8, \mathrm{CH}$ & $6.09^{\mathrm{b}}$ & 11,15 & $124.4, \mathrm{CH}$ & $6.27, \mathrm{t}(11)$ & 11 & $123.8, \mathrm{CH}$ & $6.26, \mathrm{t}(11)$ \\
\hline 14 & $122.5, \mathrm{CH}$ & $6.10^{b}$ & 12,16 & 123.0, $\mathrm{CH}$ & $6.23, \mathrm{t}(11)$ & 16 & $122.9, \mathrm{CH}$ & $6.23, \mathrm{t}(11)$ \\
\hline 15 & $137.8, \mathrm{CH}$ & 5.25 , brt (9) & $13,17,21$ & 139.3, $\mathrm{CH}$ & 5.32 , brt (9) & 13 & $138.7, \mathrm{CH}$ & 5.31 , brt (9) \\
\hline 16 & $35.0, \mathrm{CH}$ & $2.45, \mathrm{~m}$ & & $36.4, \mathrm{CH}$ & $2.55, \mathrm{~m}$ & & $36.1, \mathrm{CH}$ & $2.55, \mathrm{~m}$ \\
\hline $17 a$ & 42.7, $\mathrm{CH}_{2}$ & $0.98, \mathrm{~m}$ & & $43.0, \mathrm{CH}_{2}$ & $1.02, \mathrm{~m}$ & & $42.8, \mathrm{CH}_{2}$ & $1.03, \mathrm{~m}$ \\
\hline $17 \mathrm{~b}$ & & $1.68, \mathrm{~m}$ & & & $1.82, \mathrm{~m}$ & 16,18 & & $1.84, \mathrm{~m}$ \\
\hline 18 & $68.5, \mathrm{CH}$ & $3.37, \mathrm{~m}$ & & $70.8, \mathrm{CH}$ & $3.54, \mathrm{~m}$ & & $70.3, \mathrm{CH}$ & $3.53, \mathrm{~m}$ \\
\hline $19 a$ & $35.6, \mathrm{CH}_{2}$ & $0.99, \mathrm{~m}$ & & $36.1, \mathrm{CH}_{2}$ & $1.13, \mathrm{~m}$ & & $35.6, \mathrm{CH}_{2}$ & $1.13, \mathrm{~m}$ \\
\hline $19 \mathrm{~b}$ & & $1.78, \mathrm{~m}$ & & & $1.92, \mathrm{~m}$ & & & $1.92, \mathrm{~m}$ \\
\hline $20 \mathrm{a}$ & 23.9, $\mathrm{CH}_{2}$ & $1.26, \mathrm{~m}$ & & $25.1, \mathrm{CH}_{2}$ & $1.37, \mathrm{~m}$ & & $24.8, \mathrm{CH}_{2}$ & $1.38, \mathrm{~m}$ \\
\hline $20 \mathrm{~b}$ & & $1.64, \mathrm{~m}$ & & & $1.78, \mathrm{~m}$ & & & $1.78, \mathrm{~m}$ \\
\hline $21 a$ & $32.4, \mathrm{CH}_{2}$ & $0.89, \mathrm{~m}$ & & 33.3, $\mathrm{CH}_{2}$ & $0.99, \mathrm{~m}$ & & 33.0, $\mathrm{CH}_{2}$ & $0.98, \mathrm{~m}$ \\
\hline $21 \mathrm{~b}$ & & $1.44, \mathrm{~m}$ & & & $1.55, \mathrm{~m}$ & & & $1.56, \mathrm{~m}$ \\
\hline $22 a$ & 21.7, $\mathrm{CH}_{2}$ & $1.32, \mathrm{~m}$ & $3,4,5,23$ & $22.8, \mathrm{CH}_{2}$ & $1.47, \mathrm{~m}$ & $3,4,5,23$ & $22.5, \mathrm{CH}_{2}$ & $1.46, \mathrm{~m}$ \\
\hline $22 b$ & & $1.47, \mathrm{~m}$ & $3,4,5,23$ & & $1.65, \mathrm{~m}$ & $3,4,23$ & & $1.65, \mathrm{~m}$ \\
\hline 23 & $11.3, \mathrm{CH}_{3}$ & $0.80, \mathrm{~d}(7.4)$ & 4,22 & $11.4, \mathrm{CH}_{3}$ & $0.96, \mathrm{t}(7.4)$ & 4,22 & $11.1, \mathrm{CH}_{3}$ & $0.96, \mathrm{~d}(7.4)$ \\
\hline 24 & $40.0, \mathrm{CH}_{2}$ & $1.74, \mathrm{~m}$ & $7,8,9,25$ & $35.2, \mathrm{CH}_{2}$ & $1.98, \mathrm{~m}$ & $7,8,25$ & $24.8, \mathrm{CH}_{3}$ & $1.27, \mathrm{~s}$ \\
\hline $25 a$ & $57.9, \mathrm{CH}_{2}$ & $3.46, \mathrm{~m}$ & 8,24 & $37.4, \mathrm{CH}_{2}$ & 2.97, m & 24 & & \\
\hline $25 b$ & & $3.53, \mathrm{~m}$ & 8,24 & & $3.03, \mathrm{~m}$ & 8,24 & & \\
\hline
\end{tabular}


The coupling constant of $9.7 \mathrm{~Hz}$ between $\mathrm{H} 2$ and $\mathrm{H} 3$ suggested that they are cis to each other, which was supported by a prominent NOESY cross peak between these protons. The $E$-geometry of the $\mathrm{C} 6$ to $\mathrm{C} 7$ double bond was assigned from the coupling constant of $15.6 \mathrm{~Hz}$ between $\mathrm{H} 6$ and H7. Methylene protons on C10 were diastereotopic and coupling between $\mathrm{H} 10 \mathrm{a}\left(\delta_{\mathrm{H}} 0.98\right) / \mathrm{H} 9$ $(10 \mathrm{~Hz}), \mathrm{H} 10 \mathrm{a} / \mathrm{H} 11(1.4 \mathrm{~Hz})$, and $\mathrm{H} 10 \mathrm{~b}\left(\delta_{\mathrm{H}} 1.58\right) / \mathrm{H} 11(10 \mathrm{~Hz})$ was observed, whereas coupling between $\mathrm{H} 10 \mathrm{~b} / \mathrm{H} 9$ was not observed. Analysis of these coupling constant values suggested the $9 R^{*}, 11 R^{*}$ relative configuration. The coupling constants between $\mathrm{H} 12$ and $\mathrm{H} 13$ and between $\mathrm{H} 14$ and $\mathrm{H} 15$, as well as between $\mathrm{H} 13$ and H14, were determined by analyzing the AB-multiplet for $\mathrm{H} 13$ and $\mathrm{H} 14$, which suggested that the three coupling constants were all $11 \mathrm{~Hz}$, indicating that the $\mathrm{C} 12$ to $\mathrm{C} 13$ and $\mathrm{C} 14$ to $\mathrm{C} 15$ double bonds were both $Z$. This assignment was supported by intense NOESY cross peaks H12/H13, H14/H15, H11/H14, and H13/H16. The C16 and C18 substituents of the cyclohexane ring were both equatorial, as shown by the large coupling constants observed for H16 and H18 to the adjacent axial methylene protons. The structural assignment conducted so far suggested $\mathbf{1}$ to be a dephospho-25-deamino-25-hydroxy-leustroducsin H (phoslactomycins G) (4) derivative [7,8]. Although the relative stereochemistry within the three partial structures was identical with that of leustroducsin $\mathrm{H}$ [9], due to the insulation by double bonds and the possible free rotation of the bond between $\mathrm{C} 7$ and $\mathrm{C} 8$, it was not possible to correlate the relative configurations between the partial structures nor assign that of C8 on the basis of the NOESY data. The NMR data of $\mathbf{1}$ was very close to those reported for phoslactomycins [10-13] and leustroducsins [14,15], except for those around C9 and C18, which were phosphorylated and esterified, respectively, in the latter compounds. The presence of an almost identical biosynthetic gene cluster with those previously reported for phoslactomycins (vide infra) suggests that the stereochemistry is shared between lactomycin $\mathrm{A}$ and phoslactomycins.

Lactomycin B (2) had a molecular formula of $\mathrm{C}_{25} \mathrm{H}_{39} \mathrm{NO}_{6}$ as determined by HRESIMS. Extensive 1D and 2D NMR analyses suggested that $\mathbf{2}$ had a carbon backbone identical to that of $\mathbf{1}$. Chemical shift values of $C 25$ methylene $\left(\delta_{\mathrm{H}} / \delta_{\mathrm{C}} 3.03,2.97 / 37.4\right)$ in 2 were significantly different from those in $1\left(\delta_{\mathrm{H}} / \delta_{\mathrm{C}} 3.53,3.46 / 57.9\right)$ and suggested that $\mathrm{C} 25$ was substituted by an amino group. Therefore, compound 2 was a dephosphorylated derivative of leustroducsin $\mathrm{H}$.

The molecular formula of lactomycin C (3) was determined to be $\mathrm{C}_{24} \mathrm{H}_{36} \mathrm{O}_{6}$, which is smaller than $\mathbf{1}$ by a $\mathrm{CH}_{2} \mathrm{O}$ unit. ${ }^{1} \mathrm{H}$ and ${ }^{13} \mathrm{C}$ data of $\mathbf{3}$ were almost identical to those of $\mathbf{2}$, except for the replacement of the aminoethyl group by a methyl group $\left(\delta_{\mathrm{H}} / \delta_{\mathrm{C}} 1.27 / 24.8\right)$. This substitution was confirmed by interpretation of the 1D and 2D NMR data.

\subsection{Biosynthetic Gene Cluster}

With structural difference only being exhibited in the state of phosphorylation and acylation, lactomycins can be considered as biosynthetic intermediates of phoslactomycins. Because dephospho-25-deamino-25-hydroxy phoslactomycin B (NPLM), which is closely related to lactomycin A, has been isolated from the streptomycete that produces leustroducsins [16], we suspected that our streptomycete has the same sets of biosynthetic genes to produce phoslactomycins. We set out to reveal the biosynthetic gene cluster of lactomycins by the genome analysis of Streptomyces sp. ACT232. The genome was sequenced using Illumina Hiseq, followed by assembly with CLC Genomics Workbench to give 15 contigs which cover 7.5 Mbp in total. The sequence data in this study have been deposited in GenBank under Genbank ID LC364194 and LC365285. Analyses of contigs by antiSMASH 3.0 [17] implied the presence of biosynthetic gene clusters of 32 secondary metabolites, including a gene cluster parallel to those reported for the biosynthetic gene cluster of phoslactomycin. Biosynthetic gene clusters of phoslactomycins were previously identified in two species of streptomycetes, namely Streptomyces sp. HK-803 [18-20] and Streptomyces platensis SAM-0654 [21]. Whilst they contain almost the same sets of genes, their architectures are different; the gene cluster of phoslactomycin in Streptomyces sp. HK-803 is present in one cluster, whereas the gene cluster in Streptomyces platensis SAM-0654 is dispersed into two clusters. The lactomycin cluster is composed of six genes for the biosynthesis of cyclohexanecarboxyl-CoA $(\mathrm{CHC})$ as the starter unit, 
six PKS genes, eight genes for post PKS modifications, four transporters, and two regulatory genes (Figure 2). The biosynthetic gene cluster of our strain was separately located in two contigs, as found in Streptomyces sp. SAM-0654, and all genes required for the biosynthesis of phoslactomycins exist in the genome. The deduced function of each lactomycin biosynthetic gene and identity with the previously reported corresponding genes are listed in Table 2. Our genes shared identity ranging from $83 \%$ to $98 \%$ with those of the HK803 strain and identity ranging from $83 \%$ to $97 \%$ with those of the SAM-0654 strain. The analysis suggested that the strain ACT232 should also produce a phoslactomycin class of metabolites. Nevertheless, we were not able to detect these metabolites in our culture by LC-MS, implying that the putative kinase $(\operatorname{lmT} 4)$ and acyltranferase $(\operatorname{lmT} 8)$ [22] are not functional for some reason.

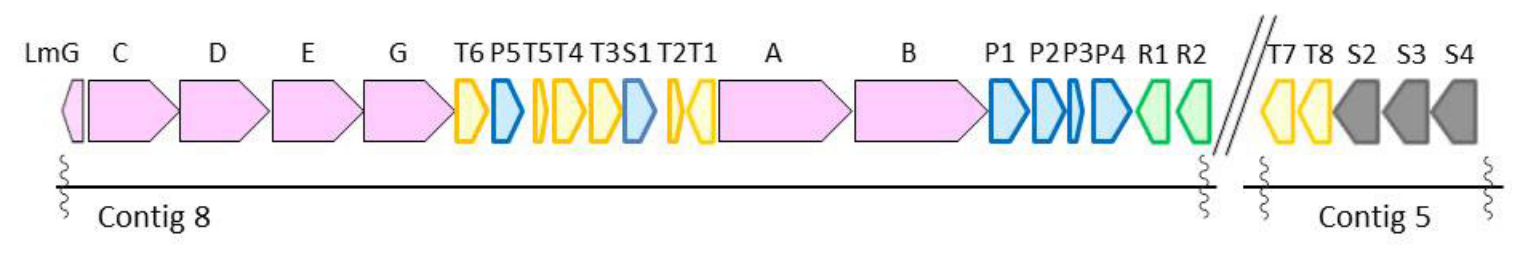

PKS Tailoring Precursor Regulatory Resistance

Figure 2. Biosynthetic gene cluster of lactomycins from Streptomyces sp. ACT232.

Table 2. Proposed funtion of ORFs in lactomycin biosynthetic gene cluster from Streptomyces sp. ACT232.

\begin{tabular}{|c|c|c|c|}
\hline \multirow{2}{*}{ Gene } & \multicolumn{2}{|c|}{ Protein Homologues, Identity (\%) } & \multirow{2}{*}{ Proposed Function } \\
\hline & S.plantensis SAM-0654 & Streptomyces sp. HK803 & \\
\hline $\operatorname{lmG}$ & pnG, 87 & plm8, 83 & Thioesterase \\
\hline $\operatorname{lmC}$ & pnC, 90 & plm4, 88 & PKS \\
\hline $\operatorname{lmD}$ & pnD, 90 & plm5, 92 & PKS \\
\hline $\operatorname{lmE}$ & pnE, 91 & plm6, 91 & PKS \\
\hline $\operatorname{lmF}$ & pnF, 92 & plm7, 93 & PKS \\
\hline $\operatorname{lmT} 6$ & pnT6, 88 & plmT8, 88 & Dehydrogenase \\
\hline $\operatorname{lmP5}$ & pnP6, 94 & plmT7, 94 & Crotonyl CoA reductase \\
\hline $\operatorname{lmT5}$ & pnT5, 92 & plmT6, 96 & Ferredoxin \\
\hline $\operatorname{lmT} 4$ & pnT4, 94 & plmT5, 98 & Protein kinase \\
\hline $\operatorname{lmT} 3$ & pnT3, 97 & plmT4, 98 & Cytochrome P450 \\
\hline $\operatorname{lmS1}$ & pnS1, 94 & plmT3, 92 & Transporter \\
\hline $\operatorname{lmT} 2$ & pnT2, 93 & plmT2, 92 & NAD dependent epimerase \\
\hline $\operatorname{lmT} 1$ & pnT1, 83 & plmT1, 84 & Aminotransferase \\
\hline $\operatorname{lm} \mathrm{A}$ & pnA, 90 & plm1, 90 & PKS \\
\hline $\operatorname{lmB}$ & pnB, 90 & plm2-3, 94 & PKS \\
\hline $\operatorname{lmP1}$ & pnP1, 92 & plmJK, 96 & AMP-dependent synthetase and ligase \\
\hline $\operatorname{lmP} 2$ & pnP2, 94 & plmL, 96 & Short-chain-CoA dehydrogenase \\
\hline $\operatorname{lmP3}$ & pnP3, 93 & ChcA, 97 & Cyclohexenylcarbonyl-CoA reductase \\
\hline $\operatorname{lmP} 4$ & pnP4, 87 & plmM, 92 & NADH:FMN oxidoreductase \\
\hline $\operatorname{lm} R 1$ & pnR1, 86 & plmR1, 94 & Regulator \\
\hline $\operatorname{lm} R 2$ & pnR2 ${ }^{a}$ & plmR2, 92 & Regulator \\
\hline $\operatorname{lmT} 7$ & pnT7, 92 & plmS2, 90 & Cytochrome P450 \\
\hline $\operatorname{lmT} 8$ & pnT8, 90 & plmS3, 90 & 18-O-Acyltransferase \\
\hline $\operatorname{lmS} 2$ & pnS2, 88 & plmS4, 85 & Transporter \\
\hline $\operatorname{lmS3}$ & PnS3, 91 & $\mathrm{ND}^{\mathrm{b}}$ & $\mathrm{ABC}$ transporter \\
\hline $\operatorname{lmS} 4$ & PnS4, 88 & ND & $\mathrm{ABC}$ transporter \\
\hline
\end{tabular}

\subsection{Biological Activity}

Lactomycin A, B, and C inhibit cathepsin B with $\mathrm{IC}_{50}$ values of $4.5 \mu \mathrm{M}, 0.8 \mu \mathrm{M}$, and $1.6 \mu \mathrm{M}$, respectively. Their inhibitory activities are moderate compared with those of known cathepsin $B$ 
inhibitors, such as E-64, which are active at a $\mathrm{nM}$ range [23]. Additionally, the cytotoxic activity of lactomycins $\mathrm{A}-\mathrm{C}$ was examined, but none of them showed activity against HeLa cells at concentrations lower than $40 \mu \mathrm{M}$.

\section{Discussion}

Phoslactomycins [10-13] and leustroducsins [14,15] are polyketides that possess $\alpha, \beta$-unsaturated $\delta$-lactone and cyclohexane moieties at both ends, which are tethered through a highly unsaturated chain with a phosphate ester. This class of compounds shows a plethora of biological activities, such as antifungal activity, inhibitory activity against protein phosphatase $2 \mathrm{~A}$, increasing the level of cytokines such as colony stimulating factors, and induction of myeloid differentiation in HL-60 cells. However, their inhibitory activity against cathepsin $B$ has not been reported so far. We noticed the structural similarity of lactomycins and leptomycins [24,25], polyketides with an $\alpha, \beta$-unsaturated $\delta$-lactone moiety and an unsaturated chain. Leptomycins are potent cytotoxins and the active site is the $\alpha, \beta$-unsaturated $\delta$-lactone moiety. However, lactomycins do not show cytotoxic activity, demonstrating that the presence of $\alpha, \beta$-unsaturated $\delta$-lactone is not sufficient for cytotoxicity.

\section{Materials and Methods}

\subsection{General Experimental Procedures}

UV spectra were measured on a Shimadzu Biospec 1600 (Shimadzu, Kyoto, Japan). NMR spectra were recorded on a JEOL alpha $600 \mathrm{NMR}$ spectrometer (JEOL, Tokyo, Japan). Chemical shifts were referenced to a solvent peak: $\delta_{\mathrm{H}} 2.49$ and $\delta_{\mathrm{C}} 40.0\left(\mathrm{DMSO}-\mathrm{d}_{6}\right)$ and $\delta_{\mathrm{H}} 3.30$ and $\delta_{\mathrm{C}} 49.0\left(\mathrm{CD}_{3} \mathrm{OD}\right)$. HRESI mass spectra were measured on a JEOL JMS-T100LC (JEOL, Tokyo, Japan). HPLC purification was carried out on a Shimadzu LC 20AT (Shimadzu, Kyoto, Japan) with an SCL-10 Avp controller and an SPD-10Avp detector.

\subsection{Collection and Identification of the Microorganism}

Deep-sea sediments were collected by the manned submersible "SHINKAI 2000" system off Hatsu-shima, Sagami-Bay, Japan, at a depth of $1174 \mathrm{~m}$, in December 2001. The sediment sample was stored in a sterilized sampler, frozen with liquid nitrogen, and transported to the laboratory, where it was kept frozen until processed. The Streptomyces sp. ACT232 was isolated from this sample. The taxonomy of the strain was determined by $16 \mathrm{~S}$ rRNA phylogenetic analysis using 27F and 1492R primers, and the sequence was deposited in the DNA Data Bank of Japan (DDBJ, accession no. AB968434).

\subsection{Fermentation, Extraction, and Isolation}

Streptomyces sp. ACT232 was cultured in $120 \times 500 \mathrm{~mL}$ Erlenmeyer flasks, each containing $250 \mathrm{~mL}$ of ISP2 medium (yeast extract $1.0 \mathrm{~g}$, malt extract $2.5 \mathrm{~g}$, glucose $1.0 \mathrm{~g}$ ) at $28^{\circ} \mathrm{C}$ on rotary shakers at $150 \mathrm{rpm}$. After 10 days of culture, the mycelia were separated by vacuum filtration. Resins (Amberlite XAD 16N, Sigma-Aldrich, MO, USA) were added to the filtrate to allow the adsorption of metabolites. The acetone extract of both the mycelia and resins was combined and then partitioned between $n-\mathrm{BuOH}$ and $\mathrm{H}_{2} \mathrm{O}$. The extract was concentrated in vacuo and separately subjected to ODS flash column chromatography eluting with $20 \%, 40 \%, 60 \%, 80 \%$, and $100 \%(v / v) \mathrm{MeOH}$ in $\mathrm{H}_{2} \mathrm{O}$. The fractions that eluted with $40 \%$ and $60 \% \mathrm{MeOH}$ were purified by ODS-HPLC (Cosmosil MSII $\phi 4.6 \times 250 \mathrm{~mm}$, Nacalai tesque, Tokyo, Japan) with gradient elution from $45 \%$ to $60 \%$ aqueous $\mathrm{MeOH}$ with $0.2 \% \mathrm{AcOH}$ to afford lactomycins A $(1.5 \mathrm{mg})$ and $\mathrm{C}(0.3 \mathrm{mg})$. The fraction that eluted with $80 \%$ $\mathrm{MeOH}$ was purified by ODS-HPLC with gradient elution from $10 \%$ to $40 \%$ aqueous $\mathrm{MeOH}$ with $0.5 \%$ AcOH to afford lactomycins $\mathrm{B}(1.5 \mathrm{mg})$

Lactomycin A (1): white solid; $[\alpha]^{20}{ }_{\mathrm{D}}(\mathrm{c} 0.09, \mathrm{MeOH})+30$; UV (MeOH) $\lambda_{\max } 230 \mathrm{~nm}(\log \varepsilon 4.12)$; ${ }^{1} \mathrm{H}$ and ${ }^{13} \mathrm{C}$ NMR, see Table 1; HRESIMS $m / z 473.2510[\mathrm{M}+\mathrm{Na}]^{+}$(calcd. for $\mathrm{C}_{25} \mathrm{H}_{38} \mathrm{NaO}_{7}, 473.2515$ ). 
Lactomycin B (2): white solid; $[\alpha]^{24}{ }_{D}(c 0.06, \mathrm{MeOH})+32$; UV (MeOH) $\lambda_{\max } 230 \mathrm{~nm}$ (log $\left.\varepsilon 2.92\right)$; ${ }^{1} \mathrm{H}$ and ${ }^{13} \mathrm{C}$ NMR, see Table 1 ; HRESIMS $m / z 472.2656[\mathrm{M}+\mathrm{Na}]^{+}$(calcd. for $\mathrm{C}_{25} \mathrm{H}_{39} \mathrm{~N} \mathrm{Na} \mathrm{O6,} \mathrm{472.2675).}$

Lactomycin C (3): white solid; $[\alpha]^{20} \mathrm{D}(\mathrm{c} 0.02, \mathrm{MeOH})+1$; UV (MeOH) $\lambda_{\max } 230 \mathrm{~nm}(\log \varepsilon$ 3.80); ${ }^{1} \mathrm{H}$ and ${ }^{13} \mathrm{C}$ NMR, see Table 1 ; HRESIMS $m / z 443.2432[\mathrm{M}+\mathrm{Na}]^{+}$(calcd. for $\mathrm{C}_{24} \mathrm{H}_{36} \mathrm{NaO}_{6}, 443.2410$ ).

\subsection{Identification of the Biosynthetic Gene Cluster}

Streptomyces sp. ACT232 was cultured in ISP2 medium for three days at $30^{\circ} \mathrm{C}$ with agitation and aeration. The genomic DNA was extracted from mycelia and isolated using QIAGEN Genomic-tip 20/G. The genome of Streptomyces sp. ACT232 was sequenced by Ilumina Hiseq to afford the data set consisting of $53,907,834$ single 100 bp reads. These reads were subjected to de novo assembly with CLC Genomics Workbench (ver8.5) to afford 15 contigs as draft genome sequences. The function of each gene was identified by antiSMASH 3.0 [17] and Blast searches. (accession number LC364194 and LC365285)

\subsection{Cathepsin B Inhibitory Assay}

A Cathepsin B inhibitory assay was performed according to a modification of the method of Hiwasa et al. [26] The enzyme (cathepsin B from bovine spleen, Sigma C6286) was stocked at $1 \mathrm{unit} / \mathrm{mL}$ in $50 \mathrm{mM}$ MES pH 6.0 and $0.1 \%$ Brij-35. The enzyme solution was diluted by 100 times with the buffer before use. The mixture of $4 \mu \mathrm{L}$ test sample solution, $100 \mu \mathrm{L}$ of the enzyme solution, and $50 \mu \mathrm{L}$ of $25 \mu \mathrm{M}$ fluorescent substrate (Z-Arg-Arg-AMC, Peptide Institute, Inc.) in DMSO was incubated at $37^{\circ} \mathrm{C}$ for $30 \mathrm{~min}$. The fluorescence of the liberated AMC was measured with an excitation at $345 \mathrm{~nm}$ and emission at $440 \mathrm{~nm}$.

Supplementary Materials: The following are available online at http:/ /www.mdpi.com/1660-3397/16/2/70/s1, 1D and 2D NMR spectra of lactomycins A (1)-C (3).

Acknowledgments: This work was partly supported by JSPS KAKENHI Grant Numbers 25252037, $16 \mathrm{H} 04980$ from the Ministry of Education, Culture, Sports, Science and Technology, Japan.

Author Contributions: K.T., S.O. and S.M. conceived and designed the experiments; Y.S., R.R.C. and Y.H. performed the experiments; K.T., K.Y. and S.A. performed genome analyses; Y.N. isolated the Streptomyces sp. ATC232; K.T. and S.M. wrote the paper.

Conflicts of Interest: The authors declare no conflict of interest.

\section{References}

1. Newman, D.J.; Cragg, G.M. Natural products as sources of new drugs from 1981 to 2014. J. Nat. Prod. 2016, 79, 629-661. [CrossRef] [PubMed]

2. Munro, M.H.G.; Blunt, J.W.; Dumdei, E.J.; Hickford, S.J.H.; Lill, R.E.; Li, S.; Battershill, C.N.; Duckworth, A.R. The discovery and development of marine compounds with pharmaceutical potential. J. Biotechnol. 1999, 70, 15-25. [CrossRef]

3. Gerwick, W.H.; Moore, B.S. Lessons from the past and charting the future of marine natural products drug discovery and chemical biology. Chem. Biol. 2012, 19, 85-98. [CrossRef] [PubMed]

4. Irie, R.; Takda, K.; Ise, Y.; Ohtsuka, S.; Okada, S.; Gustafson, K.; Matsunaga, S. Structure revision of poecillastrin $C$ and the absolute configuration of the $\beta$-hydroxyaspartic acid residue. Org. Lett. 2017, 19, 5395-5397. [CrossRef] [PubMed]

5. Gondi, C.S.; Rao, J.S. Cathepsin B as a cancer target. Expert Opin. Ther. Targets 2013, 17, 281-291. [CrossRef] [PubMed]

6. Sun, Y.; Takada, K.; Nogi, Y.; Okada, S.; Matsunaga, S. Lower homologues of ahpatinin, aspartic protease inhibitores, from a marine Streptomyces sp. J. Nat. Prod. 2014, 77, 1749-1752. [CrossRef] [PubMed]

7. Shibata, T.; Kurihara, S.; Oikawa, T.; Ohkawa, N.; Shimazaki, N.; Sasagawa, K.; Kobayashi, T.; Kohama, T.; Asai, F.; Shiraishi, A.; Sugimura, Y. Preparation of leustroducsin H and the structure-activity relationship of its derivatives. J. Antibiot. 1995, 48, 1518-1520. [CrossRef] [PubMed] 
8. Trost, B.M.; Knopf, J.D.; Brindle, C.S. Synthetic strategies employed for the construction of fostriecin and related natural products. Chem. Rev. 2016, 116, 15035-15088. [CrossRef] [PubMed]

9. Wheeler, C.R.; Trager, W.F. Absolute configuration of acenocoumarin. J. Med. Chem. 1979, 22, $1122-1124$. [CrossRef] [PubMed]

10. Fushimi, S.; Nishikawa, S.; Shimazu, A.; Seto, H. Studies on new phosphate ester antifungal antibiotics phoslactomycins. I. Taxonomy, fermentation, purification and biological activities. J Antibiot. 1989, 42, 1019-1025. [CrossRef] [PubMed]

11. Fushimi, S.; Furihata, K.; Seto, H. Studies of new phosphate ester antifungal antibiotics phoslactomycins. II. Structure elucidation of phoslactomycins A to F. J. Antibiot. (Tokyo) 1989, 42, 1026-1036. [CrossRef] [PubMed]

12. Mizuhara, N.; Usuki, Y.; Ogita, M.; Fujita, K.I.; Kuroda, M.; Doe, M.; Iio, H.; Tanaka, T. Identification of phoslactomycin E as a metabolite inducing hyphal morphological abnormalities in Aspergillus fumigatus IFO 5840. J. Antibiot. (Tokyo) 2007, 60, 762-765. [CrossRef] [PubMed]

13. Fotso, S.; Graupner, P.; Xiong, Q.; Hahn, D.; Avila-Adame, C.; Davis, G. Phoslactomycins from Streptomyces sp. MLA1839 and their biological activities. J. Nat. Prod. 2013, 76, 1509-1513. [CrossRef] [PubMed]

14. Kohama, T.; Nakamura, T.; Kinoshita, T.; Kaneko, I.; Shiraishi, A. Novel microbial metabolites of the phoslactomycins family induce production of colony-stimulating factors by bone marrow stromal cells. II. Isolation, physico-chemical properties and structure determination. J. Antibiot. (Tokyo) 1993, 46, 1512-1519. [CrossRef] [PubMed]

15. Kohama, T.; Maeda, H.; Sakai, J.I.; Shiraishi, A.; Yamashita, K. Leustroducsin B, a New Cytokine Inducer Derived from an Actinomycetes, Induces Thrombocytosis in Mice. J. Antibiot. (Tokyo) 1996, 49, 91-94. [CrossRef] [PubMed]

16. Simizu, S.; Teruya, T.; Nogawa, T.; Aono, H.; Ueki, M.; Uramoto, M.; Kobayashi, Y.; Osada, H. Deamino-hydroxy-phoslactomycin B, a biosynthetic precursor of phoslactomycin, induces myeloid differentiation in HL-60 cells. Biochem. Biophys. Res. Commun. 2009, 383, 406-410. [CrossRef] [PubMed]

17. Weber, T.; Blin, K.; Duddela, S.; Krug, D.; Kim, H.U.; Bruccoleri, R.; Lee, S.Y.; Fischbach, M.A.; Müller, R.; Wohlleben, W.; et al. AntiSMASH 3.0-A comprehensive resource for the genome mining of biosynthetic gene clusters. Nucleic Acids Res. 2015, 43, W237-W243. [CrossRef] [PubMed]

18. Palaniappan, N.; Kim, B.S.; Sekiyama, Y.; Osada, H.; Reynolds, K.A. Enhancement and selective production of phoslactomycin B, a protein phosphatase IIa inhibitor, through identification and engineering of the corresponding biosynthetic gene cluster. J. Biol. Chem. 2003, 278, 35552-35557. [CrossRef] [PubMed]

19. Alhamadsheh, M.M.; Palaniappan, N.; DasChouduri, S.; Reynolds, K.A. Modular polyketide synthases and cis double bond formation: Establishment of activated cis-3-cyclohexylpropenoic acid as the diketide intermediate in phoslactomycin biosynthesis. J. Am. Chem. Soc. 2007, 129, 1910-1911. [CrossRef] [PubMed]

20. Ghatge, M.S.; Reynolds, K.A. The plmS2-Encoded Cytochrome P450 Monooxygenase Mediates Hydroxylation of Phoslactomycin B in Streptomyces sp. Strain HK803. J. Bacteriol. 2005, 187, 7970-7976. [CrossRef] [PubMed]

21. Chen, Y.L.; Zhao, J.; Liu, W.; Gao, J.F.; Tao, L.M.; Pan, H.X.; Tang, G.L. Identification of phoslactomycin biosynthetic gene clusters from Streptomyces platensis SAM-0654 and characterization of PnR1 and PnR2 as positive transcriptional regulators. Gene 2012, 509, 195-200. [CrossRef] [PubMed]

22. Ghatge, M.S.; Palaniappan, N.; Alhamadsheh, M.M.; DiBari, J.; Reynolds, K.A. Application of a newly identified and characterized 18-O-acyltransferase in chemoenzymatic synthesis of selected natural and nonnatural bioactive derivatives of phoslactomycins. Appl. Environ. Microbiol. 2009, 75, 3469-3476. [CrossRef] [PubMed]

23. Lecaille, F.; Kaleta, J.; Bpoemme, D. Human and parasitic papain-like cysteine proteases: Their role in physiology and pathology and recent developments in inhibitor design. Chem. Rev. 2002, 102, 4459-4488. [CrossRef] [PubMed]

24. Hamamoto, T.; Seto, H.; Beppu, T. Leptomycins A and B, new antifungal antibiotics. I. Taxonomy of the producing strain and their fermentation, purification and characterization. J. Antibiot. (Tokyo) 1983, 36, 639-645. [CrossRef] [PubMed]

25. Hamamoto, T.; Seto, H.; Beppu, T. Leptomycins A and B, new antifungal antibiotics II Structure elucidation. J. Antibiot. (Tokyo) 1983, 36, 646-650. [PubMed] 
26. Hiwasa, T.; Fujita-Yoshigaki, J.; Shirouzu, M.; Koide, H.; Sawada, T.; Sakiyama, S.; Yokoyama, S. c-Ha-Ras mutants with point mutations in Gln-Val-Val region have reduced inhibitory activity toward cathepsin B. Cancer Lett. 1993, 69, 161-165. [CrossRef] 